\title{
PEMELIHARAAN FASILITAS WATER TAP \\ (Studi Kasus pada ITB dan UNS)
}

\author{
Gustauli Bintoro \\ Ilmu Administrasi Negara, Fakultas Ilmu Sosial dan Ilmu Politik, Universitas Sebelas Maret, \\ essususegar@gmail.com
}

\begin{abstract}
Abstrak
Pemeliharan fasilitas atau logistik merupakan merupakan salah satu fungsi manajemen logistik yang berupa serangkaian kegiatan atau proses yang di dalamnya berupa segala bentuk perawatan, pemeliharaan dan penjagaan keadaan barang agar barang-barang yang dimiliki oleh suatu organisasi agar tetap dapat digunakan kapanpun serta mampu mencapai umur ekonomis dari barang tersebut. Tulisan ini akan membahas tentang bagaimana perawatan fasilitas kran air siap minum yang diadakan oleh Institut Teknologi Bandung dan Universitas Sebelas Maret. Tulisan ini menggunakan kajian deskriptif kualitatif. untuk menjelaskan pemeliharaan fasilitas kran air siap minum termasuk adanya faktor-faktor yang menjadi penghambat dalam pelaksanaannya. Hasilnya ditemukan bahwa selain permasalahan pada unit pengolahannya, juga terdapat masalah pada jaringan perpipaan. Hal ini yang menjadi penghambat dalam pelaksanaan pemeliharaan fasilitas water tap itu. Selain itu, partisipasi pengguna fasilitas juga menjadi hal yang penting karena jika water tap tidak digunakan maka sirkulasi air akan menjadi tidak lanjar dan air yang tertampung pada pipa dan tandon akan tercermar bakteri yang akan terus berkembang biak dan air akan hanya dibuang menjadi limbah. Karenanya baik pihak pengelola fasilitas maupun pengguna fasilitas harus menjaga dan merawat fasilita kran air siap minum ini dengan benar.
\end{abstract}

Kata Kunci: pemeliharaan logistik, water tap, fasilitas publik.

\begin{abstract}
Maintenance of facilities or logistics is one of the functions of logistics management in the form of a series of activities or processes in which in the form of all forms of care, maintenance and care of the state of the goods for goods owned by an organization to remain usable at any time and able to achieve the economic age of the goods. This paper will discuss how the treatment of ready-to-drink water faucet facilities held by the Institute of Technology Bandung and Sebelas Maret University. This paper uses a qualitative descriptive study. to explain the maintenance of ready-to-drink water faucet facilities including the presence of inhibiting factors in their implementation. The results were found that in addition to problems in the processing unit, there are also problems in the piping network. This is an obstacle in the maintenance of water tap facilities. In addition, the participation of facility users is also important because if the water tap is not used then the water circulation will become not lanjar and the water that is accommodated on the pipe and the tank will be reflected bacteria that will continue to multiply and the water will only be disposed of into waste. Therefore both the facility manager and the facility user must maintain and care for the fasilita tap water ready to drink this properly.
\end{abstract}

Keywords: maintenance of logistics, water taps, public facilities.

\section{PENDAHULUAN}

Air merupakan salah satu kebutuhan dasar seluruh makhluk hidup. Air digunakan untuk berbagai keperluan oleh manusia seperti minum, mencuci, mandi, dan lain sebagainya. Ketersediaan air minum adalah satu bagian terpenting yang harus terpenuhi. Lambat laun, ketersediaan air untuk kebutuhan minum mengalami berbagai permasalahan mulai dari kualitas air, kuantitas dan kontinuitas air minum. Kebutuhan air minum semakin meningkat dari waktu ke waktu. Bertambahnya kebutuhan air berbanding lurus dengan kenaikan jumlah populasi manusia di seluruh dunia. Dengan demikian, manusia mulai memikirkan alternatif yang futuristik dan ramah lingkungan untuk memenuhi kebutuhan air minum, misalnya dengan pengolahan air tanah. Hasil pengolahan air baku menjadi air minum, harus dapat didistribusikan secara efektif untuk memenuhi kebutuhan manusia dalam satu cakupan area tertentu. Dewasa ini distribusi air siap minum di Indonesia mulai mengadopsi cara-cara yang dipakai di negara maju, yaitu dengan menggunakan watertap dimana air yang mengalir adalah 
air siap minum. Pendistribusian air harus dengan perencanaan yang baik, agar air minum dapat mengalir secara optimal di setiap water tap.

Di Eropa, wastewater treatment melewati tahapan awal yang seragam. Awalnya, air limbah dibiarkan dalam sebuah tangki pengendapan. Kemudian, lumpur dan kotoran yang mengendap di dasar tangki dibersihkan. Setelah itu, air diolah dengan proses biologi, dengan menggunakan bakteri. Setelah melalui tahapan awal, barulah air limbah diolah dengan metodemetode tertentu seperti membrane filtration, reverse osmosis, penggunaan ozon dan UV, dan sebagainya. Terlepas dari teknologi perawatan air, ekosistem dapat memainkan peran penting dalam pemurnian air itu sendiri. Dalam kondisi yang tepat, penggunaan ekosistem lahan basah, untuk pengolahan air limbah khususnya, merupakan situasi yang berpotensi untuk dimanfaatkan. Karena selain menyediakan pengolahan air yang efektif, ekosistem juga dapat membuat habitat yang sangat dibutuhkan untuk beberapa makhluk yang terancam. (Dhinny, 2015)

Berbicara mengenai suatu fasilitas, maka tidak lepas dari pemeliharaan fasilitas itu sendiri. Pemeliharan fasilitas atau logistik merupakan merupakan salah satu fungsi manajemen logistik yang berupa serangkaian kegiatan atau proses yang di dalamnya berupa segala bentuk perawatan, pemeliharaan dan penjagaan keadaan barang agar barang-barang yang dimiliki oleh suatu organisasi agar tetap dapat digunakan kapanpun serta mampu mencapai umur ekonomis dari barang tersebut sesuai dengan masa pakai barang tersebut yang pada dasarnya bertujuan untuk menjaga keberlangsungan kegiatan organisasi agar tetap efektif dan efisien. (Febriyanto, 2014)

Pemeliharaan Logistik adalah setiap kegiatan untuk mempertahankan kondisi teknis, daya guna, dan, daya hasil logistik baik usaha yang berifat preventig maupun represif sehingga setiap logistik yang ada senantiasa merupakan logistik yang siap pakai dan umur pemakaian logistik mencapai batas waktu yang optimal. (Dwiantara \& Sumarto, 2005)

Tahap pemeliharaan logistik lebih sulit dibanding pada tahap pengadaan logistik, hal ini dapat dilihat dari beberapa fasilitas yang telah diadakan atau disediakan, namun pada akhirnya fasilitas tersebut tidak mendapat perawatan yang baik dan semestinya sehingga mengalami percepatan penurunan nilai ekonomis dan lebih cepat rusak. Hal tersebut dapat mengakiabtkan terjadinya ketidak efektifan dan tidak efesiennya fasilitas tersebut, dan justru hanya akan menjadi sumber pemborosan pada penyedia fasilitas tersebut.

Melihat banyaknya lembaga dan beberapa kawasan di Indonesia yang mulai menerapkan fasilitas water tap ini, tulisan ini penting untuk dibahas karena banyak fasilitas watertap yang mendapat pemeliharaan kurang baik. Salah satu contohnya fasilitas water tap pada Institut Teknologi Bandung yang diresmikan pada tahun 2005, Namun, pada kenyataannya hingga saat ini water tap di ITB sudah tidak berfungsi lagi karena buruknya pemeliharaan dari water tap itu sendiri. Pada tahun 2008 fasilitas ini sempat dapat digunakan namun selang dua tahun berikutnya fasilitas water tap kembali rusak dan tidak bisa dipakai kembali. Kemudian dilakukan perbaikan sampai design dari water tap itu sendiri menjadi lebih menarik, tetapi sayang semua itu hanya dijadikan hiasan dan airnya sendiri tidak keluar sampai tahun 2012. (Gloria, 2012)

Universitas Sebelas Maret (UNS) merupakan salah satu universitas di Indonesia yang memiliki Sistem Pengolahan Air Minum (SPAM). Produk dari SPAM adalah berupa water tap dan water dispenser yang terdapat di beberapa tempat di UNS.

Gejala yang sama terlihat pada fasilitas water tap yang terdapat pada Universitas Sebelas Maret. Universitas Sebelas Maret Surakarta membangunan Sistem Penyediaan Air Minum (SPAM) hasil kerjasama dengan Kementerian Pekerjaan Umum dan Perumahan Rakyat. SPAM UNS yang diklaim mampu menghasilan 28 ribu liter air yang dapat langsung dikonsumsi tentunya sangat memantu civitas akademika Universitas Sebelas Maret Surakarta dalam memenuhi kebutuhan akan air minum (Fera, 2016). Tetapi keberadaan dan kegunaan air siap minum ini, belakangan dari beberapa tempat mengalami kerusakan karena tidak terurus. Banyak water tap dan dispenser SPAM UNS yang tersumbat bahkan mati total sudah tidak mengeluarkan air lagi.

Maraknya inovasi di bidang teknologi di Indonesia berupa pengadaan fasilitas seperti fasilitas keran air siap minum ini tentunya bermanfaat bagi banyak pihak. Selain menghemat pengeluaran dana untuk membeli air minum kemasan, kran air siap minum juga dianggap lebih ramah lingkungan karena dapat mengurangi penggunaan limbah plastik. Dengan adanya fasillitas tersebut tentunya dibutuhkan pula perawatan atau maintanance yang tepat serta partisipasi pengguna fasilitas dalam merawat kran air siap minum tersebut agar fasilitas tersebut dapat senantiasa digunakan dengan maksimal. Namun, perawatan terhadap fasilitas kran air tersebut perlu dipertanyakaan. Terdapat kasus dari beberapa fasilitas kran air siap minum yang dikeluarkan oleh beberapa instanis tersebut tidak mencapai umur pemakaian yang optimal

\section{METODE}

Tulisan ini menggunakan kajian deskriptif kualitatif. Jenis kajian deskriptif kualitatif yang digunakan 
pada penelitian ini dimaksudkan untuk menjelaskan dan menggambarkan atau mendeskripsikan pemeliharaan fasilitas kran air siap minum di Indonesia termasuk adanya faktor-faktor yang menjadi penghambat dalam pelaksanaannya.

Untuk mencapai tujuan dari penelitian yang dilakukan, maka digunakan metode berdasarkan pendekatan Kitchenham dan Charters yaitu menggunakan metode systematic literature review. Tahapan dalam systematic literature review adalah menentukan research question, proses pencarian, study selection, quality assessment, dan proses ekstraksi data (Kitchenham \& Charters, 2007). Tulisan ini dilakukan dengan meninjau studi literatur melalui 2 database yaitu, scopus dan googlescholar. Pencarian dilakukan dengan menggunakan kata kunci "maintanance", "water tap", dan "public facility".

\section{HASIL DAN PEMBAHASAN Hasil}

Langkah pertama yang dilakukan oleh penulis ialah mencari literatur yang relevan dengan tulisan yang akan dibahas mengenai Pemeliharaan Fasilitas Kran Air Siap Minum. Oleh karena itu, penulis mencari dengan 3 kata yang terkait yaitu "maintanance", "water tap", dan "public facility". Pencarian dilakukan menggunakan dua database: scopus dan google scholar. Dari hasil pencarian yang dilakukan hanya 10 studi yang memenuhi kriteria, sebagai berikut:

Tabel 1 Pencarian Literatur

\begin{tabular}{|l|c|}
\hline Database & Literatur \\
\hline scopus & 7 \\
\hline Google Scholar & 3 \\
\hline
\end{tabular}

Dari kesepuluh jurnal pada tabel diatas berisi beberapa bahasan, dalam satu jurnal berisi lebih dari satu bahasan. Lalu ditemukan, terdapat 7 jurnal yang berkaitan dengan keuntungan dari distribusi air yang baik, 2 jurnal berkaitan dengan kontaminasi bakteri dalam air, 5 jurnal berisi perawatan penyediaan air, dan 2 jurnal membahas peran konsumen dalam menjaga fasilitas air bersih.

Selain melakukan pencarian literatur melalui kedua database di atas, penulis juga melakukan pencarian artkel berita melalui situs situs yang menampilkan berita atau informasi yang berkaitan dengan bahasan ini. Pencarian ini penulis lakukan guna mencari tahu lokasi atau instasi mana saja kah di Indonesia yang terlah menggunakan berupa kran air siap minum ini. Hasilnya, ditemukan Institut teknologi Bandung telah mengeleuarkan fasilitas water tap ini sejak tahun tahun
2008, namun pada tahun 2012 fasilitas tersebut sudah rusak dan tidak dapat dipakai kembali

Selanjutnya ditemukan pula fasilitas serupa yaitu water tap yang diadakan oleh Universitas Sebelas Maret dengan dibangunnya SPAM UNS pada tahun 2016. Sebagai pengguna fasilitas air siap minum SPAM UNS, penulis sangat merasakan dampak positif dari adanya fasilitas tersebut. Namun, water tap UNS ini nampaknya juga akan bernasib sama dengan water tap yang terdapat di ITB. Kran siap minum UNS mulai ditinggalkan penggunanya, tentunya dikarenakan fasilitas tersebut tidak lagi berfungsi seperti sediakala.

\section{Pembahasan}

Berdasarkan temuan pada bagian "hasil" dapat terlihat bahwa terdapat banyak keuntungan dari perawatan penyediaan sarana fasilitas air ini, namun kita tetap harus waspada dan menjaga agar air tersebut tidak tercemar dan terkontaminasi bakteri yang berbahaya. Maka dari itu perawatan atau maintanance dari fasilitas tersebut harus dilakukan dengan baik supaya fasilitas tersebut tetap dapat digunakan kapanpun serta mampu mencapai umur ekonomis dari barang sesuai dengan masa pakai barang tersebut. selain itu konsumen sebagai pengguna fasilitas kran air pun harus turut serta menjaga fasilitas kran air siap minum guna menunjang perawatan fasilitas.

Mengenai fasilitas water tap yang diadakan oleh Institut Teknologi Bandung yang sempat rusak pada tahun 2012. Hal ini tidak lain dikarenakan maintanance yang dilakukan terhadap fasilitas tersebut tidak maksimal, penyedia dan pengguna fasilitas water tap ITB tidak menjaga keberlansungan fasilitas dengan baik, sehingga fasilitas tersebut sempat tidak dapat dimanfaatkan.

Namun, hal ini dapat teratasi setelah diadakan pembersihan terhadap unit-unit water tap tersebut. Unitunit pengolahan yang terdiri dari ozonisasi, filtrasi, mikrofilter, ultrafilter, reverse osmosis, dan UV membutuhkan perawatan (maintenance) teratur setiap jangka waktu tertentu. Setelah unit-unit tersebut direvitalisasi, maka tap water siap dikonsumsi kembali oleh masa kampus ITB. Setelah dilakukan beberapa penelitian, diketahui bahwa selain permasalahan pada unit pengolahannya, juga terdapat masalah pada jaringan perpipaannya. Oleh karena itu, Direktorat Pengembangan ITB membentuk Tim Pelaksana Revitalisasi Penyediaan Air Minum (Tap Water) di Kampus ITB-Ganesha yang diketuai oleh Rofiq Iqbal, S.T., M.Eng., Ph.D. Beliau juga menghimbau agar fasilitas water tap ini tetap digunakan. Iqbal menjelaskan bahwa pemakaian yang terus-menerus itu lebih baik sehingga air tidak lama diam di dalam pipa. Jika air terlalu lama berada di dalam pipa, ada kemungkinan lama kelamaan bakteri akan berkembang disana. (Putri, 2014) 
Tidak jauh berbeda dengan yang dialami oleh water tap ITB, water tap di UNS pun mendapat beragam tanggapan dari kalangan civitas akademika. Alih-alih guna mempermudah dalam hal konsumsi air minum, dalam kenyataannya masih banyak pihak yang kurang memanfaatkan fasilitas tersebut. "Pemanfaatan air dispenser itu belum maksimal, makanya di tandon SPAM banyak yang nggak kepakai airnya," jelas Dr. Ir. Solichin, M.T., selaku kepala divisi SPAM UNS. Padahal air spam yang tidak segera dikonsumsi, dapat membahayakan konsumen karena banyak bakteri yang tumbuh di dalamnya. Mengatasi hal tersebut, pihak SPAM mengalihkan bentuk produk menjadi air minum kemasan yang kita kenal UNSQUA. (Awwali, 2017)

Banyak mahasiswa yang masih ragu dengan kualitas air dispenser SPAM UNS. Menanggapi hal tersebut, pihak SPAM menyatakan bahwa produk air disepenser sudah teruji layak konsumsi di UPT Laboratorium Terpadu UNS. Kurangnya antusiasme mahasiswa untuk mengkonsumsi air dispenser SPAM juga disebabkan kurangnya sosialisasi dari kampus. Selain itu juga karena water tap dan water dispenser yang ada di setiap fakultas terlihat tidak terawat dan beberapa mahasiswa juga tidak mengerti serta salah dalam penggunaanya.

Meskipun demikian, keberadaan water tap dan water dispenser tetap dirasa sangat bermanfaat bagi sebagian mahasiswa lainnya. Masih terdapat mahasiswa yang meyakinkan bahwa air spam uns masih layak untuk dikonsumsi serta dapat menghemat uang saku bilamana mengkonsumsinya. Pihak SPAM menegaskan bahwa hasil produksi air dispenser SPAM benar-benar layak dikonsumsi..

Demi menjaga kualitas air SPAM itu sendiri, pihak SPAM melakukan pengecekan secara berkala terkait alatalat pemrosesan air SPAM. Mereka juga melimpahkan kewenangan perawatan water tap dan water dispenser kepada masing-masing fakultas. Walaupun kenyataanya, belum ada tindak lanjut dari fakultas atau pihak SPAM terkait beberapa air dispenser SPAM yang mengalami kerusakan. Demi pemanfaatan air dispenser SPAM yang lebih baik, beberapa mahasiswa menyarankan pihak yang bersangkutan untuk memaksimalkan sosialisasi pada mahasiswa serta pengelolaan yang meliputi perawatan dan pengecekan kondisi water dispenser maupun water tap yang ada. (Awwali, 2017)

\section{PENUTUP}

\section{Simpulan}

Banyak keuntungan yang didapatkan dari fasilitas water tap ini tentunya jika dilakukan dengan perawatan yang baik dan benar, kontaminasi dari bakteri pun dapat dihindari jika perawatan dari fasilitas ini sudah baik. Maka pengguna fasilitas juga harus menggunakan dan ikut merawat fasilitas dengan baik, bukan justru merusaknya. Salah satu kontribusi pengguna fasilitas dalam merawat water tap ini dapat dilakukan dengan cara tetap terus menggunakan dan mengkonsumsi air dari water tap itu. Karena pemakaian water tap secara terusmenerus akan melancarkan sirkulasi air dan air tidak lama diam di dalam pipa. Jika air terlalu lama berada di dalam pipa, ada kemungkinan akan terkontaminasi bakteri dan bakteri akan berkembang. Apa bila air terlalu lama tertampung didalam tandon penampungan, maka air yang tertampung tersebut harus dibuang karena ada kemungkinan bakteri sudah berkembang di dalam air dalam tandon tersebut dan justru air tersebut hanya akan menjadi limbah.

Terkait dengan fasilitas water tap SPAM UNS yang sudah mulai banyak yang rusak dan ditinggalkan, tentunya sangat disayangkan mengingat banyak civitas yang terbantu oleh kehadiran fasilitas tersebut. Namun, jika melihat pendahulunya yaitu water tap yang diadakan oleh ITB, fasilitas water tap dapat direvitalisasi dan diaktifkan kembali dengan melakukan perbaikan dan perawatan kembali. Perawatan yang dilakukan oleh pihak pengelola water tap itu sendiri diantaranya diadakan pembersihan terhadap unit-unit water tap tersebut. Unitunit pengolahan yang terdiri dari ozonisasi, filtrasi, mikrofilter, ultrafilter, reverse osmosis, dan UV membutuhkan perawatan (maintenance) teratur setiap jangka waktu tertentu.

Jika melihat dari teori yang diutarakan oleh Dwiantara \& Sumarto pada tahun 2005, perawatan logistik yang diterapkan oleh pihak ITB dan UNS belum dilakukan secara baik dan maksimal. Pihak pengelola sudah melakukan usaaha mempertahankan kondisi teknis, daya guna, dan, daya hasil logistik baik usaha yang berifat preventig maupun represif namun tidak maksimal sehingga setiap logistik yang ada tidak selalu siap pakai dan umur pemakaian logistik tidak mencapai batas waktu yang optimal. Hal ini dapat terlihat dengan banyaknya fasilitas water tap yang rusak dan tidak dapat kembali digunakan.

\section{Saran}

Demi pemanfaatan air dispenser SPAM yang lebih baik, penulis mewakli beberapa mahasiswa yang merasa membutuhkan fasilitas water tap tersebut menyarankan pihak yang bersangkutan untuk memaksimalkan sosialisasi pada mahasiswa serta pengelolaan yang meliputi perawatan dan pengecekan kondisi water dispenser maupun water tap yang ada sehingga semua unit logistik air kran siap minum tersebut dapat berfungsi 
secara lebih maksimal dan dapat dimanfaatkan dengan baik.

\section{DAFTAR PUSTAKA}

Awwali, N. A. (2017, juni 1). Ledak. Polemikair minum (spam), keberadaan, p. $2 \& 6$.

Andaru K, Bagus (2016) Analisi Kuantitas Suplai Air Minum di Universitas Sebelas Maret. Other thesis: Universitas Sebelas Maret.

Animashaun, I.A. 1989. Making public water taps run in Calabar municipality, Nigeria

B, Kitchenham, and S, Charters. 2007. Guidelines for performing systematic literature reviews in software engineering. Technical report, Ver. 2.3 EBSE Technical Report. EBSE.

Dhinny, P. (2015). Inovasi Teknologi Pengolahan Air di Beberapa Negara dan Perusahaan. 01-13 .

Dwiantara, L., \& Sumarto, R. (2005). Manajemen logistik. jakarta: Grasindo.

Febriyanto, W. (2014, Februari 23). Pemeliharaan dan penghapusan logistik. Diambil kembali dari pemeliharaan dan penghapusan logistik: http://wahyufisipuns.blogspot.com/2014/02/pemelihar aan-dan-penghapusan-logistik.html

Fera, S. (2016, April 29). SPAM Kampus dan Prasangka Terus Menerus. Diambil kembali dari saluransebelasmaret: http://saluransebelas.com/spamkampus-dan-prasangka-terus-menerus/

Gloria, G. (2012, Maret 2). Ke mana “Water Tap” ITB? Diambil kembali dari jurnalismeitb: https://jurnalismeitb.wordpress.com/2012/03/02/kemana-water-tap-itb/

Putri, L. M. (2014, februari 6). Fungsikan Tap Water Kembali, Warga ITB Tak Perlu Repot Mencari Air Minum. Retrieved from Institut Teknologi Bandung: https://www.itb.ac.id/news/read/4186/home/fungsikan -tap-water-kembali-warga-itb-tak-perlu-repotmencari-air-minum

Rafiee, M., Mesdaghinia, A., Hajjaran, H., Hajaghazadeh, M., Miahipour, A., Jahangiri-Rad, M. (2014) The efficacy of residual chlorine content on the control of Legionella spp. in hospital wa ter systems

Sarkar, R., Prabhakar, A.T., Manickam, S., Selvapandian, D., Raghava, M.V., Kang, G., Balraj, V. (2007) Epidemiological investigation of an outbreak of acute diarrhoeal disease using geographic information systems

Stolzman, Donald A. 1978. Performance An D Economic Benefits Of Mitigating Corrosion In Your Distribution System.
Tamar Makova, Grégoire Meylanb, Jon T. Powell a,c, Alon Shepond. 2016. Better than bottled water?Energy and climate change impacts of on-the-go drinking water stations

Thomas, S. 2004. Whose Law $n$ is it, anyway?

Nurlaila,I., Dewi, R,G., Kombaitanc, B,B. \& Yuliar, S. 2013. Technological Transition Planning on Residential Sector to Practice Energy Conservation Policy. University of Westminster. London.

Wright, E.P., Collins, C.H., Yates, M.D. (1985) Mycobacterium xenopi and Mycobac terium kansasii in a hospital water supply 